\title{
COSTS AND RETURNS IN ALTERNATIVE POULTRY EGG PRODUCTION MANAGEMENT SYSTEMS IN TWO LOCAL GOVERNMENT AREAS OF OGUN STATE OF NIGERIA
}

\author{
A. B. AyANWALE AND A. S. BAMIRE \\ Department of Agricultural Economics, Obafemi Awolowo Univeristy, Ile-Ife. Nigeria. \\ Received 7 December, 1994; Accepted 29 December, 1995
}

\begin{abstract}
Costs and returns involved in the intensive and semi-intensive management systems of poultry egg production were examined in ljebu-Ode and Odogbolu Local Government Areas of Ogun State in Nigeria with a view to identifying the more profitable of the two systems. Data were obtained through structured questionnaires from the respondents who were selected through the simple random sampling procedure. Descriptive and Budgetary techniques were employed to analyse the data. Results from the analysis revealed that intensive poultry management system is more profitable than the semi-intensive system as indicated by the Benefit-Cost ratio estimated at 2.2:1 and 2.0:1 for the two systems respectively. Further analysis revealed that majority ( $50 \%$ ) of farmers under the Intensive system of management undertook egg production enterprise only against none under the semi-intensive management system. Egg production averaged $132 \mathrm{egg} / \mathrm{bird}$ and $68 \mathrm{eggs} / \mathrm{bird}$ respectively for the intensive and semi-intensive systems. It was concluded that poultry egg production under intensive management system need be encouraged under the present economic condition in the country. This could be effected by providing the right economic policies aimed at reducing the cost of livestock feeds and day old chicks.

Key words: Costs, Returns, Management Systems, Egg.
\end{abstract}

\section{INTRODUCTION}

Poultry is looked upon both as a means of livelihood and a way of achieving a certain level of economic independence. Infact, poultry production offers the greatest scope for 'increasing the quality and quantity of animal protein in Nigeria (FMANR0, 1980). However, the management system adopted by a poultry farm operator depends on the purpose for which the birds are reared and, on the capital resources at the farmer' disposal. The three techniques of poultry management include the free range, the semi-intensive and the intensive management systems. The free range system allows birds to roam freely about to feed and is suitable where there is no shortage of land. Smith (1990) described the semi-intensive system as involving the enclosure of birds in runs made of wire nettings. Birds move about in the runs during the day and are kept in poultry houses at nightfall. In the intensive management system, birds are either kept in cages, fold system or in deep litter all year rounds Ogunfowora et al (1975) revealed that the rate of expansion of the intensive poultry management system in Nigeria has greatly reduced due to the high feed costs arising largely from rising prices of raw materials and inefficiency in production and distribution from feed manufacturing industries. They claimed that egg production is most efficient under the intensive management system but that the cost of foed represents about $80 \%$ of the total costs which thereby reduces expected returns to the farm-operator.

Though the intensive poultry management system is popular and syponymous with the poultry trade, government policy in the form of the Structural Adjustment Programme (SAP) has taken its toll on the intensive managment systen and hence on the poultry industry as a whole. This is because the policy has disrupted the importation of grains, feed additives, day-old chicks and medicants such that poultry farm operators are now faced with the alternative of searching for cheaper 


\section{AYANWALE}

systems of raising the birds. As one of the cheap means of raising livestock, the semiintensive system is becoming more patronised. However, there is need to examine the possible economic gains associated with the semi-intensive management system vis-a-vis the intensive management system especially under the present economic dispensation in the country. Thus, in order to ascertain the most profitable approach of the two management systems, this paper reports the findings of the study of the costs and returns associated with the two management systems in Ogun State of Nigeria.

Specifically, the study objectives were to examine and/or estimate:

(i) the socio-economic characteristic of poultry farmers associated with both the intensive and semi-intensive management systems in the study area;

(ii) costs and returns associated with the intensive and semi- intensive management systems.

\section{MATERIALS AND METHODS}

Two local government areas, Ijebu-Ode and Odogbolu, in Ogun State of Nigeria were chosen for the study.

Data were obtained from forty poultry farmers within February and May, 1992 using structured questionnaires administered through personal interviews. Information were collected on farmers socio-economic characteristics, costs and returns from egg production, and on problems associated with the management system employed.
A multi-stage random sampling procedure was employed. The study area was divided into village groups and, nine towns/villages located at distance varying between $10 \mathrm{~km}$ and $20 \mathrm{~km}$ from the local government headquarter (Ijebu-Ode) were randomly selected for the study. 40 poultry farmers were then purposively selected altogether for interview with sample size proportional to the poultry farming population in each village (Table 1). Data were analysed with descriptive and budgetary techniques, according to Akinsoye, (1989). It was employed in this study to determine the costs and returns to the factors of production under the intensive and semi-intensive management systems

The Total Cost of production can be obtained from equation 1.

$\mathrm{TC}=\mathrm{FC}+\mathrm{VC}$

where

$\mathrm{TC}=$ total cost of production; and

$\mathrm{FC}=$ cost of using resources whose quantities are fixed during the production period (e.g. cost of equipment, housing, land, etc.)

$\mathrm{VC}=$ Cost of using resources whose quantities vary during the production period (e.g. labour feeds, day-old chicks).

Net return to the poultry farmer is obtained from equation 2:

$U=$ Net profit, and TR $=$ total revenue (product of unit price and quantity of the product sold).

Profitability ratios were then employed to explain the extent to which a poultry farmer employs the factors at his disposal optimally in order to achieve some desired goals.

TABLE 1; DISTRIBUTION OF RESPONDENTS BY TOWNS/VILLAGES

\begin{tabular}{lcl}
\hline Towns Villages & No. of Respondent & Percentages of Total \\
\hline Jiebu-Ode & 16 & 40 \\
Iloti & 4 & 10 \\
liese & 4 & 10 \\
Isonyin & 3 & 75 \\
Enunwon & 3 & 7.5 \\
Odogbolu & 4 & 10 \\
Ala & 3 & 7.5 \\
Idowra & 2 & 5.0 \\
Ogbo & 1 & 2.5 \\
\hline Total & 40 & $100 \%$ \\
\hline
\end{tabular}

Source: Field survey, 1992. 
These include:

(i) Expense Sinucture ratio

(ii) BenefituCost mis

(iii) Gross ratio

(iv) Rate of Retum on livestment

$\frac{\text { Net Return }}{\text { TC }} \times \frac{100}{1}$

\section{RESULTS AND DISCUSSION}

Tables 2 and 3 reveal that the average variabie cost expended per bird under șemi-intensive management system was N53.19 while the intensive system recorded N54.35. The higher figure for the intensive system was because poultry egg production under this system utilized high-cost feed and, with the birds confined, the amount of money spent on feed consumption and medicare per bird was very high. However, the lower figure under the semi- intensive management system was because the poultry farmers only provided a percentage (about two-thirds) of the food requirement by the birds, while the remaining onc-third were provided by greens, insects and worms consumed by the birds.

The profit margin obtained (Table 3) was much higher under the intensive management system than the semi-intensive system. While the intensive system yielded a net return of $\$ 73.62$ per bird, the semi-intensive system yielded $\mathbf{N 7 0 . 4 7}$ per bird. The expense structure ratio revealed that more money was expended on fixed cost items under the semi-intensive system than under the intensive system. This resulted in a lower production cost and hence high profitability of the intensive management system as shown in Table 4. This is supported by the figures obtained for the Benefit-Cost ratio and the Gross ratio respectively.

Thus, results from the budgetary technique revealed that poultry egg production under the intensive management system was more profitable than the semi-intensive management system in the study area.

\section{Socb-economic Chanctiotatics of Poultry tammere}

Table 5 reveals that 36 put of the 40 respondent-farmers operated the intensive

Nigerian Jouthal of Animal Production 23(2) 1996 management syatem while only 4 farmers operated under the semi-intensive system. It is observed that 18 poultry farmers $(50 \%)$ practising the intensive management system operate egg production enterprise against none under the semi-intensive system.

The age distribution of respondents also reveals that $52.78 \%$ were between ages 41 and 50 years while $2.78 \%$ aged above 60 years under the intensive system. However, majority (75\%) of the respondents fall within the ages of 20 years and 40 years under the semi-intensive system. This shows that majority of the farmers venturing into poultry production under the semi- intensive system comprised young enterprising men.

Weekly feed consumptiom from the 52-week annual production period in Table 6 shows that bird under the intensive management system can consume from 1 bag to greater than 242 bags per week while under the semi-intensive system, birds consume within 1 bag and 161 bags per week. This underscores the high cost associated with the feed requirement of birds under the intensive management system. Most of the feed sources were said to be either from the market or selfformulated by own feed mill.

It was gathered that the factors militating against poultry farmers' production efforts ranged from high feed costs and scarcity, to lack of capital emanating from the inability to secure loanable funds, lack of infrastructural facilities such as accessible roads, pipe-borne water and electricity, inadequate and high cost of equipment, and the rising cost and quality of day-old chicks. A small percentage of the farmers however, mentioned disease problems as majority of them had access to veterinary officers who inoculate and vaccinate birds in the area. Consequently, the moriality rate recorded from the field study was low and only varied between $6 \%$ and $13.3 \%$.

In conclusion, the total cost of production to the point-of-lay per bird under the intensive management system was not as high as the cost under the semi-intensive system, while revenue per bird under semi-intensive was lower than that under the intensive management system. 


\section{TABLE 2; AVERAGE PRODUCTION COSTS AND RETURNS FOR INTENSIVE POULTRY MANAGEMENT SYSTEM}

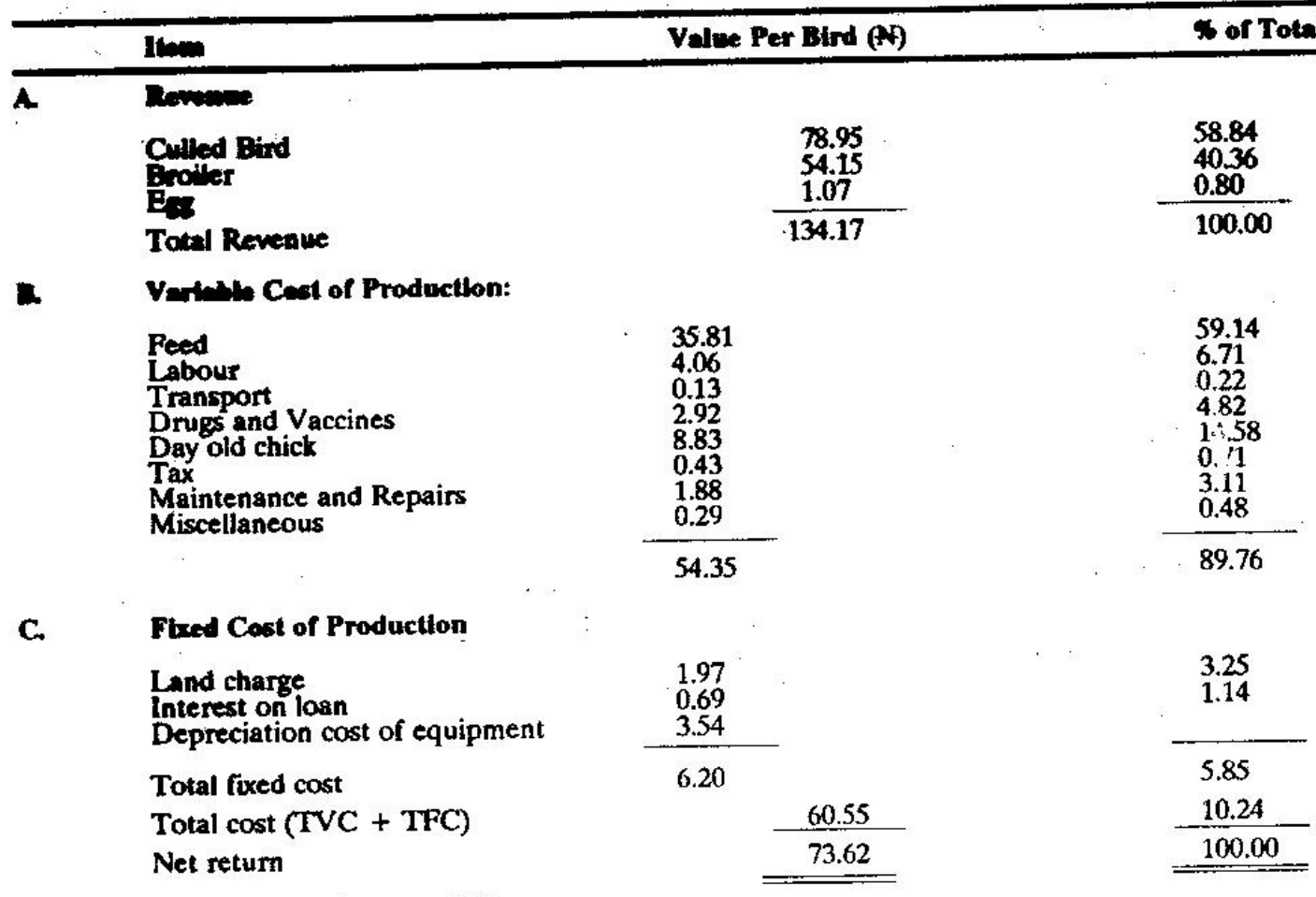

Source: Field Survery, 1992.

TABle 3: AVERAGE PRODUCTION COSTS AND RETURNS FOR SEMI-INTENSIVE POULTTRY MANAGEMENT SYSTEM

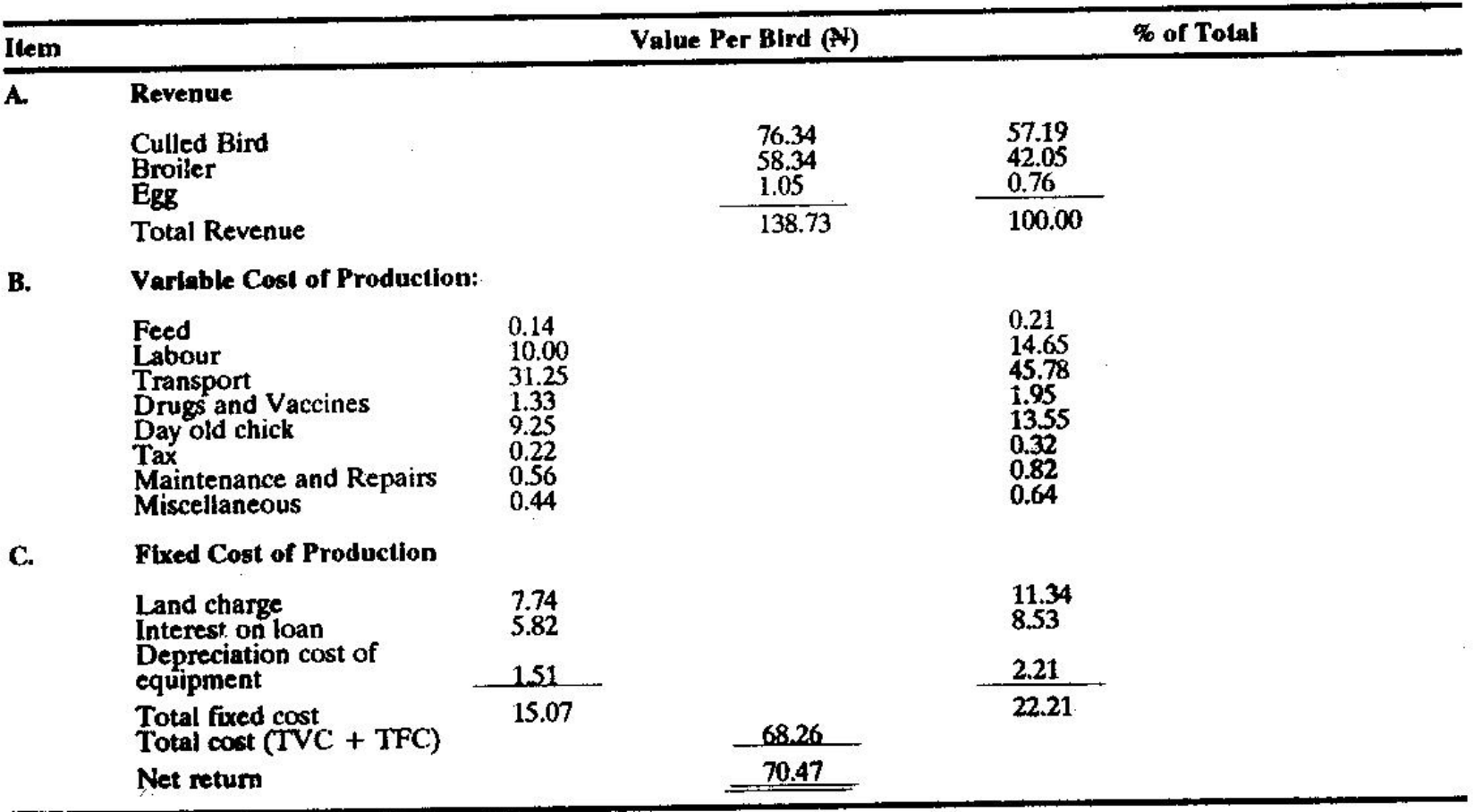

Source: Field Survey, 1992. 


\section{COST AND RETURNS IN EGG PRODUCTION SYSTEMS}

Though poultry production under both management systems was profitable, the Benefit-Cost ratio for the intensive sydem was higher than for the semi-intentive system (2.22:1) and 2.03:1 respectively). Additionally, profit margin under-jentensive managemennt system estimated at $\$ 73.62 \mathrm{k}$ was higher that that under the semi-intensive system of \#70.47k. Annual egg production figures also revealed that the intensive management system produced 132 eggs/bird while the semi-intensive system produced 68 egas/bird.
Based on the results of this study, there is need to effect governmental policies aimed at reducing the cost of livestock production. This may take the form of encouraging commercial grain (especially maize) production and its sale at affordable prices. Apparently, the current economic climate with continually increasing costs of production does not favour semi- intensive poultry production more than the intensive system since expected returns also increase in the same vein, the main efforts of government therefore need to be targeted on the reduction of critical cost items.

\section{TABLE 4: COMPARATIVE PROFITABILITY RATIO FOR INTENSIVE AND SEMI- WTENSIVE MANAGEMENT SYSTEMS}

\begin{tabular}{|c|c|c|c|}
\hline Inem: & & Intensive System/Bird & Sernb-inlenetve Bird System \\
\hline Expene Structure Ratio (ESR) & & $0.10: 1$ & $0.22: 1$ \\
\hline Besefix Coat Ratio (BCR). & 2.22:1 & 2.0 & \\
\hline Grom Ratio (GR) & & $0.45: 1$ & $0.49: 1$ \\
\hline Rate of Returns on Investment (ROI) & & $122 \%$ & $103 \%$ \\
\hline
\end{tabular}

Sowree: Field Surver, 1992.

TABLE 5: POULTAY ENTERPRISE BY TYPE

\begin{tabular}{|c|c|c|c|c|c|}
\hline \multicolumn{2}{|c|}{ Type } & \multicolumn{2}{|l|}{ Intensive System } & \multicolumn{2}{|c|}{ SemI-ia,tensfve System } \\
\hline 1. & Ere Production anly & 10 & & & \\
\hline & Egg Production only & 18 & 50 & - & 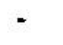 \\
\hline 2. & Egg and Broiler Production & 12 & 33.33 & 2 & 50 \\
\hline \multirow[t]{2}{*}{3.} & Broiler Production & 6 & 16.67 & 2 & So \\
\hline & Total & 36 & 100.00 & 4 & 100 \\
\hline
\end{tabular}

Source: Field Survey, 1992.

TABLE 6: WEEKLY FEED CONSUMPTION (BAGS)

\begin{tabular}{|c|c|c|c|c|}
\hline \multirow[b]{2}{*}{ Range (Bogs) } & \multicolumn{2}{|c|}{ Intensive System } & \multirow{2}{*}{$\begin{array}{c}\text { Seni-intensive System } \\
\text { Frequency }\end{array}$} & \multirow[b]{2}{*}{$\%$} \\
\hline & Frequency & $\%$ & & \\
\hline $1+80$ & 21 & 58.34 & 3 & 75 \\
\hline $81 \cdot 161$ & 9 & 25.00 & 1 & 25 \\
\hline $162 \cdot 242$ & 3 & 8.33 & - & - \\
\hline Over 242 & 3 & 8.33 & - & - \\
\hline Total & 36 & 100.00 & 4 & 100 \\
\hline
\end{tabular}

Source: Field Survey, 1992 


\section{REFERENCES}

ABAELE, J. N. (1964): "Cost and Return of Private Commercial Egg Production "in Ibadan area. A Pilot Investigation" Bulletin of Rural Economic and Sociology 1 (1): 75 85.

AKINSOYE, O. F. (1989): Profitability of Poultry Production in Oranmiyan Local Government Area of Oyo State". B. Agric. Thesis the Department of Agric. Economics, Obafemi Awolowo Univeristy, Ile-Ife, (Unpublished).

F. A. O. (1965): Protein requirements: FAO Nutritional Management Report Series 37.

FOOD STRATEGIES MISSION (1980): The Green Revolution, A Food Production Plan for Nigeria. A study conducted for the Federal Ministry of Agriculture.
IKPI, A.E; AKINWUMI, J.A. and ADEGEYE, AJ. (197): "Poultry Industry in Nigeria: The 1977 Situation". Journal of Rural Economics and Development 11(2).

OGUNFOWORA, O.B.; FETUGA, B.L.; ADEMOSUN, A.A.; OFFIONG, S.A.; AKINOLA, A. and KOOPMAN, J. (1972): "Survey of the Livestock Feed Situation in Nigeria." Report to the Federal Livestock Department, Lagos, Nov., 1975.

ONI, C.O. (1984): "Eccinomics of Poultry Production in Atakumosa, llesa and Obokun Local Government Areas of Oyo State". A Thesis submitted to the Department of Agricultural Economics, Obafemi Awolowo University, lle-Ife (Unpublished).

SMITH, J. A. (1990): "The Tropical Agriculturist: Poultry" Macmillan Publishers. 